他の変化は認めない，以上のととより症例 2 は，組織 学的には症例 1 とほぼ同样な所見を呈するが，骨榷中 に病坚がひろがつており, 線維組織, 巨細胞, 出血 坚等多く，腫痛的性格が強いように思われ，我々は non-osteogenic fibroma と診断した。

御枍閲をいただいた玉井教授に深謝する。
文献

1) Henry, L. Jaffe : Tumors and Tumorous Conditions of the Bones and Joints p. 76, 1961.

2) 前山: 整形外科. 11(7): 431, 1960 .

3) 長谷川: 整形外科. 14(2): 145, 1963.

4) 山口: 整形外科. 8(5):297, 1957.

5) 北川：臨床整形外科. $2: 1046,1967$.

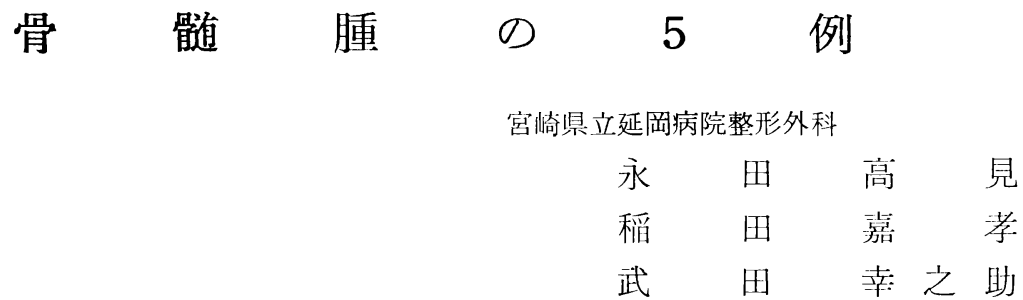

\title{
Five Cases of Multiple Myeloma
}

By

\section{T. Nagata, Y. Inada \& K. Taketa \\ Miyazaki Prefectual Nobeoka Hospital, Orthopedic Clinic}

\footnotetext{
We have encountered 5 cases of multiple myeloma since 5 years, 4 cases had died, 1 case is alive.

The chief complaints were the pain on the low back, back and breast, and anemia.

Diagnosis :

2 Cases by the examinational excision.

2 Cases by the marrow puncture smears.

1 Case by the clinical views and the radiographic appearances.

The anemia and the accentuation of the red cell sedimentation rate were counted on the case of all.

Hyperglobulinemia: 2 cases.

Bence-Jones Proteinuria: 1 case.

Radiograph showed osteoporosis, punched out rundish rarefactions and fractures.

The differential diagnosis from osteoporosis, increasing recently, schould be careful.
}

従来比較的稀なものとされていた多発性骨髄䛲は近 年検查法や診断技術の向上と共に增加の傾向が著しく なつて来た。我々は最近 5 年間に 5 例の経験を得たの で報告する。

症例 140 才 女子 電話交換手

昭和 38 年 11 月初, 左腸骨部に疼痛を訴元, 同時に 腰部にズキズキする感じがあり, 溸次疼痛増強し, 12
月 12 日より仕事を休んだ。 12 月 14 日当科を受彮し， 骨盤腪焬の疑いで精查手術が奖められたが入院しなか つた。 昭和 39 年 1 月上り肋骨・有胛骨・鎖骨・腸骨 部に疼痛を訴え，全身衰弱著明なるため，1月28日 入院した。

家族歴・既往歴：特記するてとはない。

入院時所見: 顔面萑白, 眼瞼結膜貧血性, 頸部りン 
パ腺の 腫脹なく、胸腹部には 異常は認められなかつ た. 胸骨・鎖骨・肋骨・左腸骨部に吅打痛・圧痛が認 められた。

レ線像：頭蓋骨・左腸骨に小円形状の打抜き像の点 在が認められた。

検查所見: 赤沈 1 時間值 $56 \mathrm{~mm}$, 赤血球数 328 万, 血色素量 $59 \%$ ，r-グロブリン $51.5 \%$ でその他に著変 は認められなかつた。

経過：腸骨より試験切除を行ない診断を確定, 輸 血, アミノ酸, ステロイド, マイトマイシン等を使用 したが効果なく，昭和 39 年 3 月 26 日死しした。

\section{症例 277 才子}

昭和 41 年 4 月誘因なく腰痛を訴え体動時に 増悪す る. 5 月腰痛は烈しくなり起立歩行は不能となり 5 月 25 日入院した。

家族歴・既往歴に特記するととはない。

入院時所見：全身衰弱高度, 顔貌やや苦悶状で顔面 やや荅白, 肝は 2 横指触知され, 腰椎部々吒打痛 - 圧 痛，殊に運動痛が著明に認められた。

レ線像：腰椎に Osteoporose 高度で一部不明瞭な 骨破壊が点在し椎体の圧平化がみられ，頭蓋骨にも小 透明像が諗められた。

検査所見：赤沈值 1 時間 $104 \mathrm{~mm}$, 赤血球数 295 万, 血色素量 $57 \%$, 血清蛋白量 $8.2 \mathrm{~g} / \mathrm{dl}, r$-グロブリン $52.0 \%$, 骨咀穿刺にて形質細胞様腫煬細胞の著明な増 加が証明された。

経過：ギプスベット安静，トヨマイシン，コップ, ウレタン等を使用したが, 漸次疼痛, 全身衰弱增悪 し，8月 25 日退院，その後数力月で死亡した。

症例 346 才子 農漁業

昭和 42 年 6 月出漁中舟の中で転倒し，それ以来時 々腰痛を訴えた。10月初, 腰痛著明で某医に入院, 顔 面下肢の浮揰並びそ蛋白尿があり, 筲炎と腰椎の圧迫 骨折の診断で治療を受けたが漸次貧血, 腰痛, 全身衰 弱増悪し，鼻出血が持続し， 12 月 23 日入院した。

入院時所見 : 全身衰弱貧血高度で鼻出血之頭痛持続 し, 顔面は浮腫状荅白であつた。春椎, 肋骨, 胸骨に 圧痛があり，肍骨の各所に小腫瘤が認められた。

レ線像：頭蓋骨には小円形状の打抜き像が点在し， 肋骨, 骨盤, 大腿骨には打抜き像, 蜂䆚状構造が, 胸 腰椎にびまん性のOsteoporose と一部に圧迫骨折が 認められた（第1図）。

検査所見：赤沈 1 時間值 $178 \mathrm{~mm}$, 赤血球数 73 万,

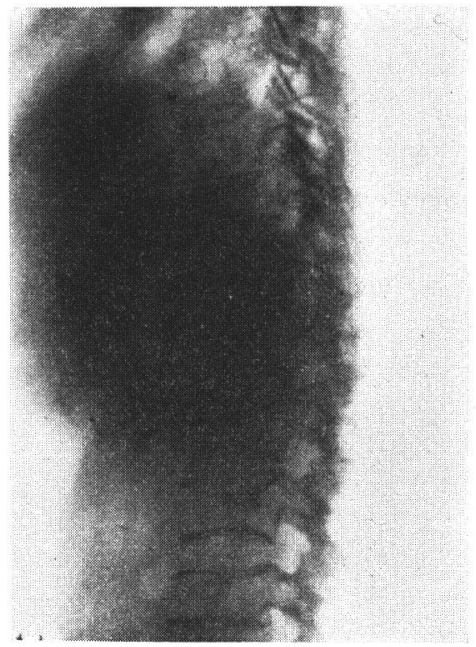

第1図（症例 3）

血色素量 $24 \%$ ，血清蛋白量 $12.0 \mathrm{~g} / \mathrm{dl}, \boldsymbol{\gamma}$-グロブリン $66.2 \%$, 残余窒素 $75.3 \mathrm{mg} / \mathrm{dl}$, 骨髄穿刺（形質細胞） $11 \%$ ，尿蛋白 $(+)$, Bence-Jones 蛋白 $(+)$.

経過：新鮮血の注入により, 出血傾向軽快, 残余窒 素值も改善され，一時全身状態も回復したか子見えた が，昭和 42 年 2 月 6 日肺炎，尿毒症を合併し死亡し た。

\section{症例 457 才 男子 会社員}

昭和 43 年 2 月より背部腰部に 疼痛を訴え，労働に より增悪の傾向があり，某医にて変形性脊椎症といわ れ，軟性コルセットを装着していたが漱次貧血が増悪

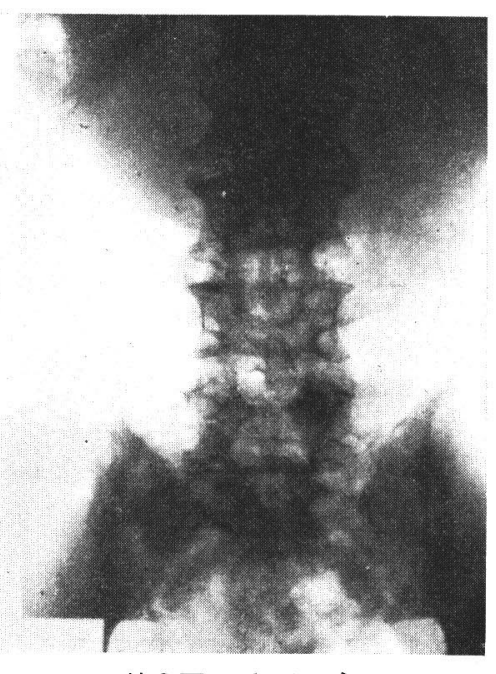

第2図（症例 4） 
するため，5月 20 日本科に入院した。

入院時所見：顔面やや浮腫状で荅白，胸腹部に異常 なく, 肋骨 - 胸腰椎に圧痛, 介達痛運動痛が認められ た。

レ線像：骨盤，大腿骨，肩胛骨，上腕骨に打抜き 像, 蜂䆚状構造の混在があり, 胸腰椎には変形, 骨硬 化，一部に不明瞭な骨破壊像の点在が認められた（第 2 図).

検査所見: 赤沈 1 時間值 $21 \mathrm{~mm}$, 赤血球数 222 万, 血色素量 $48 \%$ ，血清アルカリフォスファターゼ 133.0 単位 (Armstrong), 残余窒素 $46.3 \mathrm{mg} / \mathrm{dl}$, . 尿䖵白 (一), Bence-Jones 蛋白 (一), 骨髄中の形質細胞増 加 (-).

経過：貝血高度なるため大量の新鮮血，保存血在使 用したが一時的な効果のみで衰弱増悪し，昭和 43 年 9 月 10 日死亡した.

\section{症例 565 才男子}

昭和 43 年 1 月誘囚なく腰痛を訴光，体動により増 悪，某医にて治療を受けていたが軽快せず，6月初よ り胸部, 背部に疼痛出現し, 烈しい時は睡眠も障害さ れるようになり，6月15日入院した。

入院時所見: 栄養状態不良, 顔面やや蒼白肋骨胸骨 に圧痛, 介達痛があり, 背腰部には運動痛が著明に認 められた。

レ線像：頭蓋骨に打拔き像が，骨盤，大腿骨には打

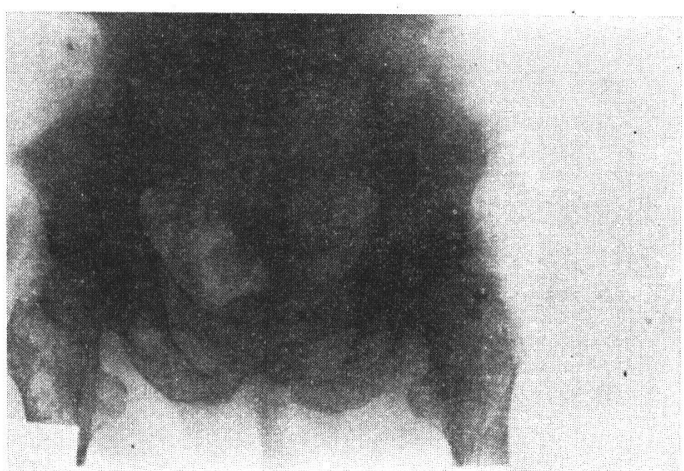

第3図（症例 5)

抜き像と蜂窩状構浩が混存し，胸腰椎にはびまん性の Osteoporose と多数の圧迫骨折加認められた（第 3 闵).

娭查所見: 赤沈 1 時間值 $32 \mathrm{~mm}$, 赤血球数 376 万, 血色素量 $65 \%$ ，骨䯣中形質細胞增加 (一), BenceJones 蛋白 (一).

経過：全身状態概放良好で肋骨部の圧痛以外大した 疼痛もないので, 腸骨並びに大腿骨より試験切除を施 行, 形質細胞様の成熟した腫演細胞の過形成は全く見 られず，クロマチンに濃染されたりンパ球様の小円形 細胞の増殖（おそらく未熟型形質細胞の小結節性増 殖）と破骨細胞と思われる巨細胞腫類似の核数の少な い多核巨細胞か諗められた。現在症状も落着いている

表 $\quad 1$

\begin{tabular}{|c|c|c|c|c|c|c|c|c|c|c|c|c|}
\hline 症例 & 性 & 年令 & 主 & 钵 & $\begin{array}{l}\text { 発症よ } \\
\text { 来院ま } \\
\text { の } \\
\text { 期 }\end{array}$ & $\begin{array}{l}\text { 赤沈 } \\
\text { 六進 }\end{array}$ & 貧血 & 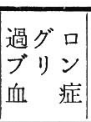 & $\begin{array}{c}\text { Bence- } \\
\text { Jones } \\
\text { 蛋白体 }\end{array}$ & $\begin{array}{l}\text { レ 線 上 } \\
\text { 発現部位 }\end{array}$ & 治 療 法 & $\left.\begin{array}{l}\text { 経 } \\
\text { 発過 } \\
\text { (症より } \\
\text { 死亡をで } \\
\text { の 期 間 }\end{array}\right)$ \\
\hline 1 & 女 & 40 & $\begin{array}{l}\text { 腰 痛 } \\
\text { 左下肢㾦 }\end{array}$ & & 1 力月 & $\uparrow$ & + & $\begin{array}{c}r-G \\
+\end{array}$ & - & $\begin{array}{ll}\text { 頭 } & \text { 蓋 } \\
\text { 骨 } & \text { 盤 }\end{array}$ & 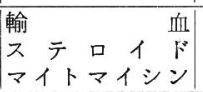 & 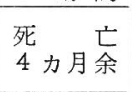 \\
\hline 2 & 女 & 77 & 腰 & 痛 & 2 力月 & $\uparrow \uparrow \uparrow$ & H & $\begin{array}{c}r-\mathrm{G} \\
+\end{array}$ & - & 腰 & 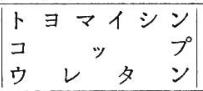 & 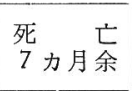 \\
\hline 3 & 女 & 46 & $\begin{array}{l}\text { 腰 痊 } \\
\text { 貧血 } \\
\text { 全身衰弱 }\end{array}$ & 痛 & 6 力月 & $\uparrow \uparrow \uparrow$ & H & $\begin{array}{c}r-\mathrm{G} \\
+\end{array}$ & + & 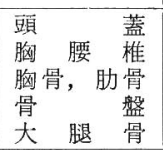 & $\left|\begin{array}{llll}\text { 輸 } & & & \text { 血 } \\
コ & & & 7^{\circ} \\
ウ & レ & \text { タ } & \text { ン }\end{array}\right|$ & $\begin{array}{l}\text { 死 亡 } \\
\text { 肺 炎 } \\
\text { 尿 毒 症 } \\
\text { 8 }\end{array}$ \\
\hline 4 & 男 & 57 & $\begin{array}{l}\text { 背 } \\
\text { 腰 }\end{array}$ & 痛 & 4 力月 & $\uparrow$ & H & - & - & $\begin{array}{l}\text { 全 脊 椎 } \\
\text { 肋骨, 肩甲骨 } \\
\text { 右上腕, 骨 } \\
\text { 胸腰椎, 骨盤 } \\
\text { 右大腿 骨 }\end{array}$ & 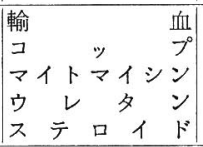 & $\begin{array}{c}\text { 死 亡 } \\
7 \text { 力月 }\end{array}$ \\
\hline 5 & 男 & 65 & $\begin{array}{l}\text { 胸 } \\
\text { 背 } \\
\text { 腰 }\end{array}$ & 桶 & 5 力月 & $\uparrow$ & + & - & - & $\begin{array}{l}\text { 頭蓋, 助骨 } \\
\text { 胸腰 椎 } \\
\text { 骨 } \\
\text { 盤 } \\
\text { 大 腿 骨 }\end{array}$ & 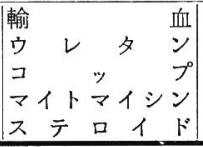 & $\begin{array}{l}\text { 入 院 中 } \\
\text { 発症後 } \\
10 \text { 月 }\end{array}$ \\
\hline
\end{tabular}


唯一の生存例である.

$$
\text { 総括 }
$$

第 1 例では検查所見は概ね揃つていたが確診に致ら ず，腸骨部試験切除により診断された。第 2 例では脊 椎骨粗㰮症を思わせるレ線像に迷つたが，胸骨穿刺所 見より彰断され，第 3 例は入院時既に未期であり，殆 んどの所見が䑪つていた．第 4 例は特徴的なもの少な く臨休像, レ線像により，第 5 は典型的なレ線像を呈 していたが，血液所見に特徴なく，腸骨，大腿骨試験 切除により異型性の強い形質細胞を盟めた（第 1 表）.

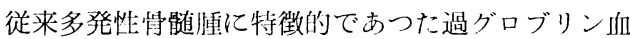
症, Bence-Jones 蛋白体， レ線像に於ける多発性の 打抜き像等の揃わない症例があり, 骨㵦像にても異型
性の強い形質細胞がかなり存在するてとが診断を困難 ならしめる。

レ線像に於いでも小円形状透明な打拢き像, 蜂窝状 構造，小破壊像，びまん性の Osteoporose 骨硬化， 圧迫骨折等種々雑多であり，他の悪性骨腫焬や脊椎骨 粗鬎症等との鑑別を要する。

\section{文献}

Jaffe, H. L.: Tumors and Tumorous Conditions of Bones and Joints, 369 .

松野. 他: 整形外科. 19(4):297, 1968.

伊丹・他：整形外科. 16(14): 1195, 1965 .

加藤 - 他 : 整形外科. $13(1): 58,1962$.

加茂：整形外科。12(12)：1016, 1961 .

\title{
左第五中手骨がん転移の一例について
}

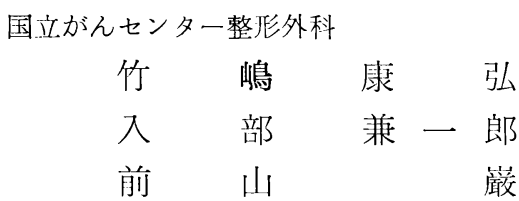

\section{The Metastatic Cancer to the fifth left Metacarpus A case report}

By

\author{
Y. Takeshima, K. Iribe \& I. Maeyama \\ National Cancer Center, Orthopedic Surgery
}

Cases of metastatic cancer to the peripheral bones are rarely seen.

This is a case report of a patient with metastatic cancer to the left fifth metacarpus.

The patient, 44 years old, male, had complained of painful swelling in his left hand for a few months' duration.

Roentgenographically an osteolytic lesion was discovered in his left metacarpus. At first enchondroma or giant cell tumor was suspected, but cytological examination demonstrated cancer cells, and histological examination revelaed adenocarcinoma.

The involved bone was resected. One month after the surgery, a tumorous mass appeared at the supraclavicular lymph node, and osteolytic lesions in the skull and right calcaneus were discovered. The primary lesion was found in the lung after the general survey for two months.

がんの骨転移は未期症状の一つとして日常しばしば 見られるが, 多くの場合, 脊椎, 骨盤, 肋骨, 大腿
骨，頭蓋骨など中枢部に近い骨に好発し，四肢末梢骨 への転移をみることは稀である。1966 年, 前山, 佐藤 